\title{
PEMBANGUNAN GAME EDUKASI BELAJAR BAHASA SUNDA BERBASIS ANDROID MENGGUNAKAN CONSTRUCT2 DAN ADOBE PHONEGAP
}

\author{
Sultan Maulana Husein ${ }^{1}$, Peti Savitri ${ }^{2}$ \\ ${ }^{1,2}$ Program Studi Teknik Informatika, Fakultas Teknik \\ Universitas Sangga Buana \\ sultanmaulanahusein@gmail.com ${ }^{1}$, petisavitri@gmail.com²
}

\begin{abstract}
ABSTRAK
Adanya minat serta rasa ketertarikan belajar yang tinggi diperlukan untuk mempermudah proses pembelajaran pada anak. Sedangkan saat ini kegiatan pembelajaran di sekolah dasar mayoritas masih menggunakan media berupa Buku panduan, yang menyebabkan kurangnya rasa ketertarikan dan perhatian siswa untuk mengikuti pembelajaran sehingga siswa mengalami kesulitan saat memahami materi-materi pembelajaran yang disampaikan. Untuk mengatasi masalah tersebut diperlukan adanya sebuah media pembelajaran berupa Game Edukasi yang dapat menambah minat serta rasa ketertarikan belajar pada anak, yang di dalamnya menyajikan permainan yang mudah dimainkan, warna-warna cerah, serta tampilan animasi yang menarik. Penelitian ini dilaksanakan di SD Negeri 016 Dr. Cipto Pajajaran pada mata pelajaran Bahasa Sunda. Metode pengembangan yang digunakan adalah Model Prototipe. Game ini dibangun dengan menggunakan Aplikasi Construct2 dan Adobe Phonegap.
\end{abstract}

Kata Kunci: Game, Edukasi, Android, Bahasa Sunda

\section{PENDAHULUAN}

\subsection{Latar Belakang}

Perkembangan teknologi dan informasi saat ini sudah berkembang begitu pesat, sehingga dapat berpengaruh di berbagai aspek kehidupan salah satunya di dalam bidang Pendidikan. Di dalam dunia Pendidikan, teknologi berpengaruh terhadap proses pembelajaran di sekolah dasar dan penyampaian materi dalam proses kegiatan belajar mengajar. Pada tahap pendidikan anak usia sekolah dasar, siswa cenderung lebih tertarik dengan suatu permainan yang mudah dimainkan yang di dalamnya terdapat warnawarna cerah serta gambar animasi yang menarik perhatian. Selain itu siswa juga akan lebih mudah mengingat suatu tulisan dan bentuk komunikatif, yang memiliki ciri warna menarik dan menyenangkan.

Sedangkan saat ini kegiatan pembelajaran di sekolah dasar mayoritas masih menggunakan media berupa Buku panduan, begitu pula dengan pembelajaran yang dilakukan di SD Negeri 016 Dr. Cipto Pajajaran. Pada pembelajaran Bahasa Sunda Kelas III di SD Negeri 016 Dr. Cipto Pajajaran, Guru menyampaikan materi pembelajaran dasar Bahasa Sunda sesuai dengan kompetensi dasar, seperti pengenalan nama hewan dan tumbuhan yang ada disekitar.

Setelah dilakukan observasi di sekolah, pembagian kuesioner untuk orang tua siswa dan berdasarkan hasil diskusi dengan wali kelas serta guru mata pelajaran Bahasa Sunda, dapat disimpulkan jika siswa mengalami kesulitan dalam menghafal dan menyebutkan nama hewan dan tumbuhan. Hal ini dapat dilihat pada hasil Kuesioner yang dibagikan untuk orang tua siswa, hanya 3 siswa dari jumlah keseluruhan 31 siswa yang mengaku tidak mengalami kesulitan dalam mempelajari Bahasa Sunda, 19 siswa lainnya mengaku kesulitan dan 9 siswa lainnya mengaku kadang-kadang mengalami kesulitan.

Hal ini dapat di sebabkan kurangnya rasa ketertarikan dan perhatian siswa untuk mengikuti pembelajaran yang sedang berlangsung. Selain itu, materi yang disampaikan tidak dapat dimengerti dengan baik karena media yang digunakan kurang menarik, sehingga menyebabkan siswa 
mengalami kesulitan saat memahami materimateri pembelajaran yang disampaikan.

Berdasarkan uraian di atas maka pentingnya membangun sebuah media pembelajaran game edukasi belajar Bahasa Sunda, game edukasi ini sudah menyajikan tampilan yang semenarik mungkin yang dapat mempermudah proses pembelajaran siswa dengan menggunakan konsep belajar sambil bermain, serta pentingnya dilakukan penelitan dengan judul "Pembangunan Game Edukasi Belajar Bahasa Sunda Berbasis Android Menggunakan Construct2 dan Adobe Phonegap".

\subsection{Rumusan Masalah}

Rumusan masalah yang dicoba untuk diselesaikan dari penelitian ini adalah: "Bagaimana cara membangun sebuah game yang menarik dan dapat memberikan edukasi terhadap pelajaran Bahasa Sunda pada anak"

\subsection{Maksud \& Tujuan Penelitian}

Membangun sebuah game edukasi yang dapat membantu mempermudah anak dalam mengingat nama-nama hewan dan tumbuhan dalam Bahasa Sunda.

1. Untuk memperkenalkan pelajaran Bahasa Sunda pada siswa kelas 3 SD dengan menggunakan media game.

2. Untuk mengubah mindset siswa, bahwa belajar juga bisa menyenangkan dan tidak selalu monoton.

3. Untuk menambah minat serta mengenalkan pada siswa bahwa game edukasi tidak kalah menarik dengan game non-edukasi yang ada saat ini.

4. Untuk mengetahui apakah kegiatan pembelajaran menggunakan game edukasi sudah efektif untuk diterapkan.

\subsection{Ruang Lingkup}

1. Game edukasi ini hanya diperuntukkan pada siswa kelas $3 \mathrm{SD}$.

\footnotetext{
${ }^{1}$ Wafda Adita Rifai, Skripsi: "Pengembangan Game Edukasi Lingkungan Berbasis Android" (Yogyakarta: Universitas Negeri Yogyakarta, 2015), hlm. 6.

${ }^{2}$ Restu Deliana, Skripsi: "Pembuatan Game Komodo Island Adventure Untuk Memperkenalkan
}

2. Perancangan game edukasi ini hanya meliputi desain, animasi, audio, sprite dan event sheet.

3. Game edukasi ini meliputi halaman menu yang terdiri dari halaman pembelajaran Bahasa Sunda mengenai pengenalan hewan dan tumbuhan serta halaman Kuis yang berisi tentang soal-soal latihan materi pembelajaran tersebut.

\subsection{Landasan Teori}

\subsubsection{Game}

Game atau Permainan merupakan suatu kegiatan atau aktivitas yang biasanya dilakukan dengan tujuan bersenang-senang, refreshing, berolahraga ringan atau mengisi waktu luang. Menurut Clark (2006) Game adalah kegiatan yang melibatkan keputusan pemain, berupa mencapai tujuan dengan dibatasi oleh konteks tertentu. ${ }^{l}$ Game juga dapat diartikan sebagai arena pengambil keputusan dari aksi pemainnya, karena didalam Game ada targettarget yang ingin dicapai dan juga kelincahan intelektual (Intellectual Playability) yang pada tingkat tertentu juga menjadi tolak ukur sejauh mana Game itu menarik untuk dimainkan. Menurut Andrew Rollings dan Ernest Adam (2003) genre game dapat diklasifikasikan menjadi beberapa tipe antara lain adalah ${ }^{2}$

\subsubsection{Edukasi}

Di dalam kamus besar bahasa Inggris kata "education" berarti pendidikan. Pendidikan adalah sebuah proses pembelajaran yang didapat oleh setiap manusia, dimana proses pembelajaran tersebut dilakukan terus menerus dan tidak berhenti. Pendidikan merupakan salah satu kunci terpenting di dalam kehidupan manusia, secara umum Pendidikan bertujuan untuk membantu manusia mendapatkan eksistensi kemanusiaan secara keseluruhan, Pendidikan juga bertujuan untuk membantu manusia menjadi terarah dan lebih baik di dalam segala aspek kehidupan. Sedangkan di dalam Kamus besar Bahasa Indonesia (1991) Pendidikan dapat diartikan sebagai proses

Satwa Komodo Sebagai Satwa Endemik Indonesia Dengan Metode Permainan Edugames Berbasis Desktop" (Bandung: Universitas Widyatama, 2015), hlm. 6. 
pengubahan sikap dan tata laku seseorang atau sekelompok orang dalam usaha mendewasakan manusia melalui upaya pengajaran dan pelatihan. ${ }^{3}$

\subsubsection{Game Edukasi}

Game Edukasi merupakan sebuah genre game yang di dalamnya mengandung konten pendidikan atau pengajaran, game jenis ini bertujuan untuk menarik minat belajar anakanak terhadap materi pelajaran dengan menggunakan konsep belajar sambil bermain, sehingga dengan perasaan senang diharapkan anak dapat lebih mudah memahami materi pelajaran yang disajikan. ${ }^{4}$

Menurut (Handriyantini, 2009) Game Edukasi adalah permainan yang dibuat atau dirancang untuk merangsang daya pikir, termasuk meningkatkan konsentrasi dan memecahkan masalah. ${ }^{5}$

Salah satu keunggulan yang signifikan dari game edukasi edukasi adalah adanya animasi yang dapat meningkatkan daya ingat sehingga anak dapat mengingat materi pelajaran dalam

\section{METODE PENELITIAN}

\subsection{Teknik Pengumpulan Data}

Pengumpulan data yang dilakukan dalam penelitian ini menggunakan Teknik sebagai berikut:

\section{Studi Kepustakaan}

Studi Kepustakaan merupakan kegiatan untuk menghimpun informasi yang relevan dengan masalah yang menjadi objek penelitian. Informasi tersebut dapat diperoleh dari karya ilmiah, jurnal, bukubuku, tesis, internet dan sumber-sumber lain.

\section{Teknik Pengamatan/Observasi}

Teknik Pengamatan atau Observasi merupakan metode mengumpulkan data atau

\footnotetext{
${ }^{3}$ Demmy Dharma Bhakti, "Game Edukasi Menara Hanoi Sebagai Salah Satu Alternatif Pembelajaran Logika Matematika Di SMK". Jurnal Teknologi Pendidikan dan Pembelajaran. Vol.2 No.1, Maret 2017, hlm. 256.

${ }^{4}$ Op.cit hlm. 9.

${ }^{5}$ Riwinoto, Arif Muspita, "Penerapan Multiplayer Pada Aplikasi Permainan Android". Jurnal Politeknik Negeri Batam. 2017, hlm. 2.
}

waktu yang lebih lama dibandingkan dengan metode pembelajaran Konvensional (Clark, 2006) ${ }^{6}$

\subsubsection{Bahasa Sunda}

Bahasa Sunda merupakan sebuah Bahasa dari cabang Melayu-Polinesia dalam Bahasa Austronesia. Bahasa Sunda telah dituturkan oleh kurang lebih 38 juta orang dan merupakan Bahasa Ibu dengan penutur terbanyak kedua di Indonesia setelah Bahasa Jawa. Bahasa Sunda hampir di gunakan di seluruh provinsi Jawa Barat dan Banten, juga wilayah Jawa Tengah mulai dari Kabupaten Brebes, Kabupaten Cilacap, disebagian Kawasan Jakarta serta di seluruh provinsi yang di Indonesia maupun luar negeri yang menjadi daerah urbanisasi Suku Sunda. ${ }^{7}$

Namun seiring dengan perkembangan zaman, masyarakat mulai mengabaikan Bahasa Ibu atau Bahasa daerahnya masing-masing termasuk Bahasa Sunda, Sehingga jika hal ini terus dibiarkan terjadi, Suku Sunda akan kehilangan identitas budaya daerahnya.

informasi dengan mengamati secara langsung di lapangan. Hasil observasi tersebut dijelaskan dengan rinci, akurat, teliti dan objektif.

3. Teknik Dokumentasi

Teknik Dokumentasi merupakan suatu kegiatan untuk melakukan pencarian, pengumpulan, penyelidikan dan penyediaan dokumen untuk mendapatkan informasi. Sumber informasi tersebut dapat berupa karangan atau Tulisan, buku, wasiat, undang-undang dan lain-lain.

\section{Wawancara}

Wawancara merupakan suatu metode memperoleh data untuk tujuan penelitian dengan cara melakukan tanya jawab secara

\footnotetext{
${ }^{6}$ Anik Vega Vitianingsih, "Game Edukasi Sebagai Media Pembelajaran Pendidikan Anak Usia Dini". Jurnal INFORM. Vol. 1 No.1, 2016, hlm. 25

${ }^{7}$ Ganteng Eki Pribadi, Undang Syaripudin, Wisnu Uriawan, "Aplikasi Pembelajaran Bahasa Sunda Dengan Implementasi Algoritma Linear Congruential Generator Dan Fuzzy Berbasis Android". Jurnal JOIN. Vol.1 No.1, Juni 2016, hlm. 35.
} 
langsung (face to face) antara pewawancara dan narasumber/pihak yang berkaitan dalam penelitian ini.

\section{Teknik Kuesioner}

Kuesioner merupakan metode pengumpulan data yang dilakukan dengan cara memberikan seperangkat pertanyaan atau pernyataan kepada orang lain yang dijadikan responden untuk mempelajari sikap-sikap, keyakinan, perilaku, dan karakteristiknya.

\subsection{Metode Perancangan Sistem}

Metode Prototype merupakan salah satu siklus hidup yang cepat dan pengujiannya berdasarkan pada konsep model kerja. Tujuannya adalah mengembangkan model menjadi sistem final sesuai keinginan user, sehingga sistem akan dikembangkan lebih cepat dan biayanya menjadi lebih rendah. Secara garis besar metode Prototype mempunyai langkahlangkah sebagai berikut: Analisis kebutuhan sistem, Desain sistem, Pengujian sistem dan Implementasi.

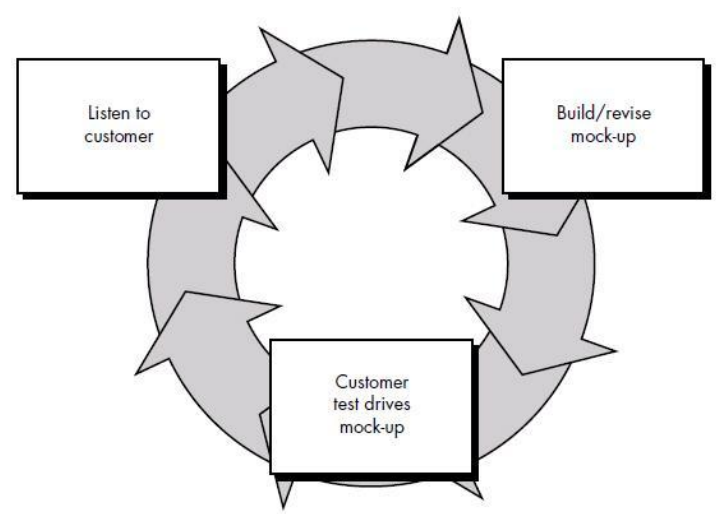

Gambar 1. Metode Perancangan Sistem

\section{HASIL DAN PEMBAHASAN}

\subsection{Deskripsi Current System}

Saat ini kegiatan pembelajaran di sekolah dasar mayoritas masih menggunakan media berupa Buku Panduan, begitu pula dengan pembelajaran yang dilakukan di SD Negeri 016 Dr. Cipto Pajajaran. Padahal pada tahap pendidikan anak usia sekolah dasar, siswa cenderung lebih tertarik dengan suatu permainan yang mudah dimainkan yang di dalamnya terdapat warna-warna cerah serta gambar animasi yang menarik perhatian, Namun sampai saat ini belum adanya media yang dapat menampung hal-hal tersebut.

\subsection{Analisis Masalah}

Proses pembelajaran menggunakan media Buku Panduan masih banyak memiliki Kelemahan, diantaranya kurangnya rasa ketertarikan dan perhatian siswa untuk mengikuti pembelajaran yang sedang berlangsung dan juga berdampak materi yang disampaikan tidak dapat dimengerti dengan baik, sehingga menyebabkan siswa mengalami kesulitan saat memahami materi-materi pembelajaran yang disampaikan. Hal ini dapat dilihat pada hasil Kuesioner yang dibagikan untuk orang tua siswa, hanya 3 siswa dari jumlah keseluruhan 31 siswa yang mengaku tidak mengalami kesulitan dalam mempelajari Bahasa Sunda, 19 siswa lainnya mengaku kesulitan dan 9 siswa lainnya mengaku kadangkadang mengalami kesulitan.

\subsection{Analisis Pengguna}

Aplikasi ini dirancang khusus untuk siswa kelas 3 SD yang memiliki karakteristik sebagai berikut :

1. Anak belajar dengan menggunakan dan merepresentasikan objek yang dilengkapi gambaran dan kata-kata. Tahap pemikirannya yang lebih bersifat simbolis tanpa melibatkan pemikiran operasional.

2. Anak SD senang bermain, karakteristik ini menuntut para pengajar untuk melakukan kegiatan pendidikan yang bermuatan permainan terlebih untuk kelas rendah.

3. Anak lebih menyukai hal-hal yang praktis.

\subsection{Use Case}

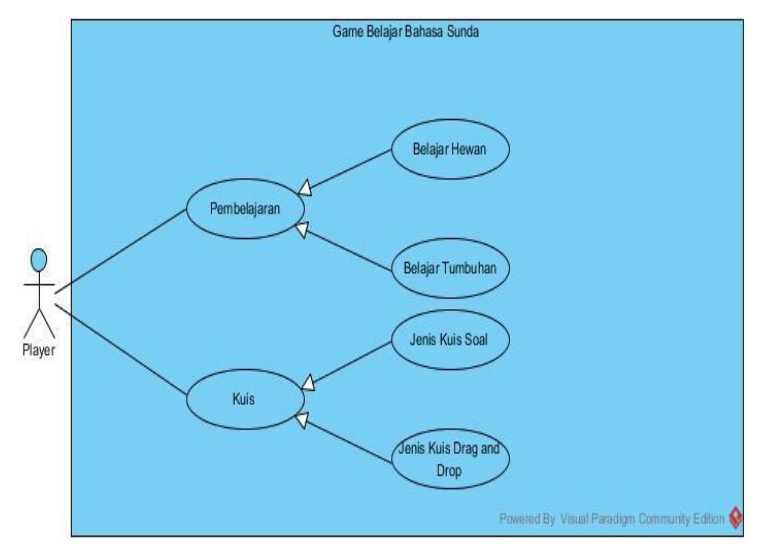

Gambar 2. Desain Kasus 


\subsection{Struktur Navigasi}

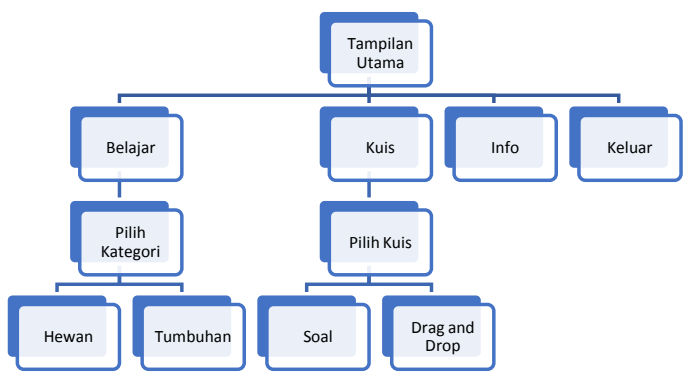

Gambar 3. Struktur Navigasi

\subsection{Implementasi Antarmuka}

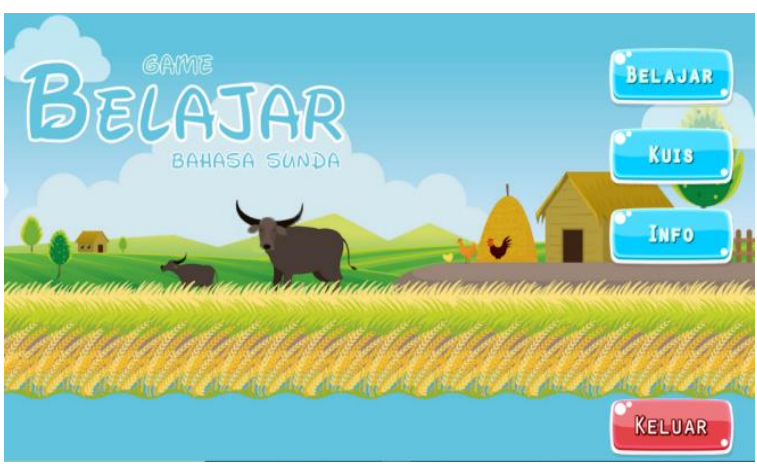

Gambar 4. Tampilan Utama

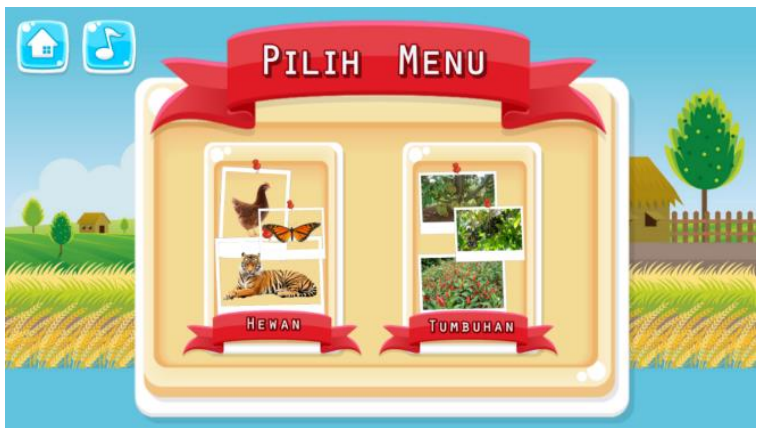

Gambar 5. Tampilan Menu Belajar

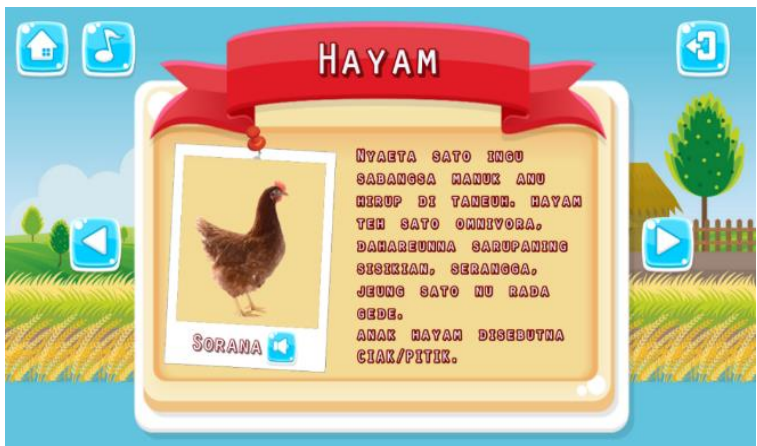

Gambar 6. Tampilan Belajar Hewan

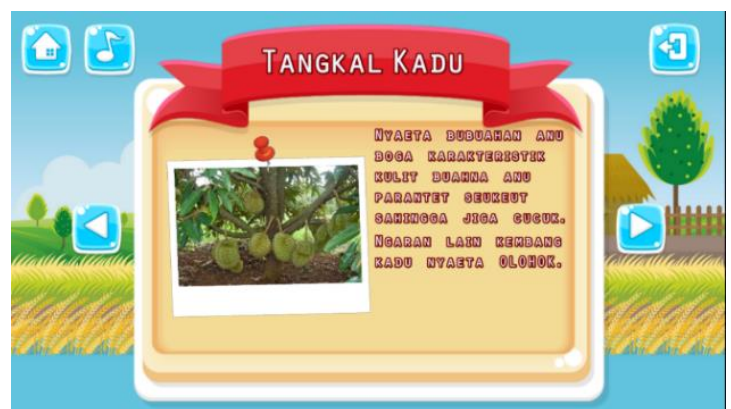

Gambar 7. Tampilan Belajar Tumbuhan

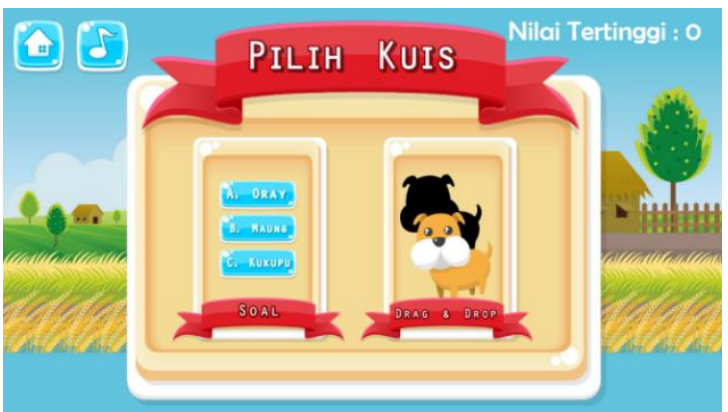

Gambar 8. Tampilan Menu Kuis

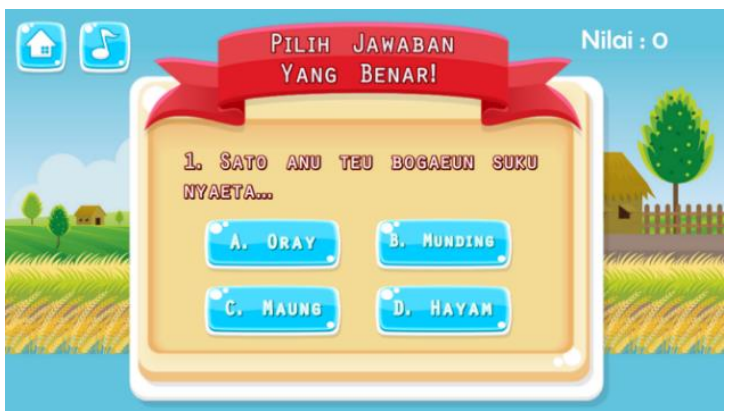

Gambar 9. Tampilan Kuis Soal

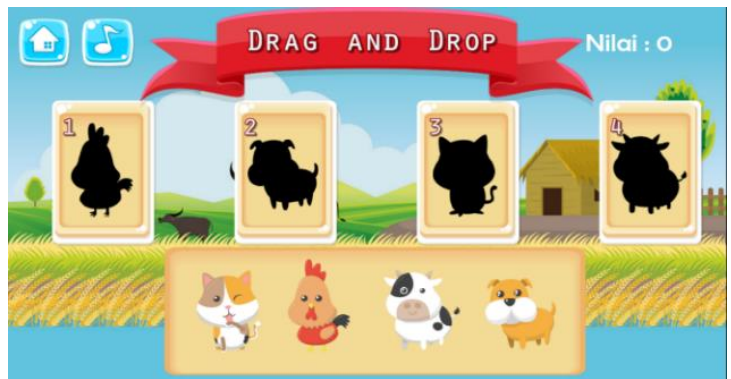

Gambar 10. Tampilan Kuis Drag and Drop

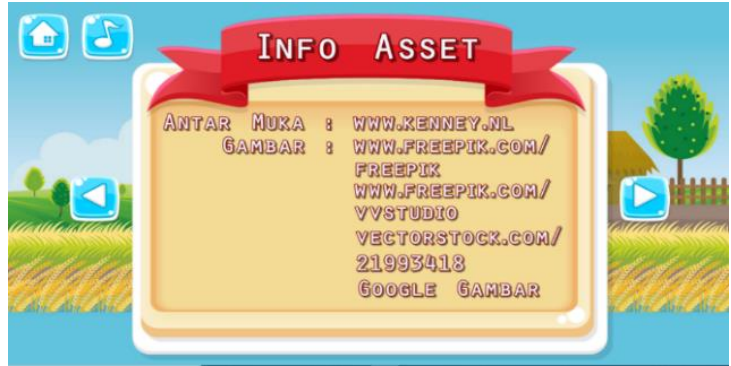

Gambar 11. Tampilan Menu Info 


\subsection{Pengujian BlackBox}

\begin{tabular}{|c|c|c|c|}
\hline Kelas Uji & Gambar & Detail Pengujian & Jenis Uji \\
\hline $\begin{array}{l}\text { Tombol } \\
\text { Belajar }\end{array}$ & BELAJAR & $\begin{array}{l}\text { Menampilkan Menu } \\
\text { Belajar }\end{array}$ & $\begin{array}{l}\text { Black } \\
\text { box }\end{array}$ \\
\hline $\begin{array}{l}\text { Tombol } \\
\text { Kuis }\end{array}$ & Kurs & $\begin{array}{l}\text { Menampilkan Menu } \\
\text { Kuis }\end{array}$ & $\begin{array}{l}\text { Black } \\
\text { box }\end{array}$ \\
\hline Tombol Info & INFO & $\begin{array}{l}\text { Menampilkan } \\
\text { Informasi seputar } \\
\text { Asset dan Game }\end{array}$ & $\begin{array}{l}\text { Black } \\
\text { box }\end{array}$ \\
\hline $\begin{array}{l}\text { Tombol } \\
\text { Keluar }\end{array}$ & KELUAR & Keluar dari Game & $\begin{array}{l}\text { Black } \\
\text { box }\end{array}$ \\
\hline $\begin{array}{l}\text { Tombol } \\
\text { Tampilan } \\
\text { Utama }\end{array}$ & & $\begin{array}{l}\text { Menampilkan } \\
\text { Tampilan Menu } \\
\text { Utama }\end{array}$ & $\begin{array}{l}\text { Black } \\
\text { box }\end{array}$ \\
\hline $\begin{array}{l}\text { Tombol } \\
\text { Musik }\end{array}$ & 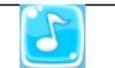 & $\begin{array}{l}\text { Menyalakan atau } \\
\text { Mematikan Musik }\end{array}$ & $\begin{array}{l}\text { Black } \\
\text { box }\end{array}$ \\
\hline $\begin{array}{l}\text { Tombol } \\
\text { Suara } \\
\text { Hewan }\end{array}$ & & $\begin{array}{l}\text { Memainkan Suara } \\
\text { Hewan }\end{array}$ & $\begin{array}{l}\text { Black } \\
\text { box }\end{array}$ \\
\hline
\end{tabular}

\begin{tabular}{|c|c|c|c|}
\hline $\begin{array}{l}\text { Tombol } \\
\text { Kembali }\end{array}$ & 뎨 & $\begin{array}{l}\text { Menampilkan Menu } \\
\text { Sebelumnya }\end{array}$ & $\begin{array}{l}\text { Black } \\
\text { box }\end{array}$ \\
\hline $\begin{array}{l}\text { Tombol } \\
\text { Halaman } \\
\text { Selanjutnya }\end{array}$ & & $\begin{array}{l}\text { Menampilkan } \\
\text { Halaman Selanjutnya }\end{array}$ & $\begin{array}{l}\text { Black } \\
\text { box }\end{array}$ \\
\hline $\begin{array}{l}\text { Tombol } \\
\text { Halaman } \\
\text { Sebelumnya }\end{array}$ & & $\begin{array}{l}\text { Menampilkan } \\
\text { Hzalaman Sebelumnya }\end{array}$ & $\begin{array}{l}\text { Black } \\
\text { box }\end{array}$ \\
\hline $\begin{array}{l}\text { Tombol } \\
\text { Jawaban }\end{array}$ & & $\begin{array}{l}\text { Menghasilkan } \\
\text { Jawaban }\end{array}$ & $\begin{array}{l}\text { Black } \\
\text { box }\end{array}$ \\
\hline $\begin{array}{l}\text { Tombol } \\
\text { Belajar } \\
\text { Hewan }\end{array}$ & 2 & $\begin{array}{l}\text { Menampilkan Menu } \\
\text { Belajar Hewan }\end{array}$ & $\begin{array}{l}\text { Black } \\
\text { box }\end{array}$ \\
\hline $\begin{array}{l}\text { Tombol } \\
\text { Belajar } \\
\text { Tumbuhan }\end{array}$ & $2 \pi$ & $\begin{array}{l}\text { Menampilkan Menu } \\
\text { Belajar Tumbuhan }\end{array}$ & $\begin{array}{l}\text { Black } \\
\text { box }\end{array}$ \\
\hline $\begin{array}{l}\text { Tombol } \\
\text { Nama } \\
\text { Hewan }\end{array}$ & $\operatorname{sonanan} a$ & $\begin{array}{l}\text { Memainkan Suara } \\
\text { Nama Hewan }\end{array}$ & $\begin{array}{l}\text { Black } \\
\text { box }\end{array}$ \\
\hline $\begin{array}{l}\text { Tombol } \\
\text { Nama } \\
\text { Tumbuhan }\end{array}$ & & $\begin{array}{l}\text { Memainkan Suara } \\
\text { Nama Tumbuhan }\end{array}$ & $\begin{array}{l}\text { Black } \\
\text { box }\end{array}$ \\
\hline $\begin{array}{l}\text { Tombol } \\
\text { Kuis Soal }\end{array}$ & & $\begin{array}{l}\text { Menampilkan Kuis } \\
\text { Soal }\end{array}$ & $\begin{array}{l}\text { Black } \\
\text { box }\end{array}$ \\
\hline $\begin{array}{l}\text { Tombol } \\
\text { Kuis Drag } \\
\text { and Drop }\end{array}$ & DRAG & $\begin{array}{l}\text { Menampilkan Kuis } \\
\text { Drag and Drop }\end{array}$ & $\begin{array}{l}\text { Black } \\
\text { box }\end{array}$ \\
\hline $\begin{array}{l}\text { Gambar } \\
\text { Drag and } \\
\text { Drop }\end{array}$ & & $\begin{array}{l}\text { Memindahkan Gambar } \\
\text { ke tempat yang telah } \\
\text { disediakan }\end{array}$ & \begin{tabular}{|l} 
Black \\
box
\end{tabular} \\
\hline Tabel Nilai & Nilai : 0 & Menampilkan Nilai & $\begin{array}{l}\text { Black } \\
\text { box }\end{array}$ \\
\hline $\begin{array}{l}\text { Tabel Nilai } \\
\text { Tertinggi }\end{array}$ & Nilai Tertinggi : 0 & $\begin{array}{l}\text { Menampilkan Nilai } \\
\text { Tertinggi }\end{array}$ & $\begin{array}{l}\text { Black } \\
\text { box }\end{array}$ \\
\hline
\end{tabular}

\section{KESIMPULAN}

\section{Kesimpulan}

1. Game ini dapat membantu mempermudah Siswa mempelajari B.Sunda dibandingkan pembelajaran di kelas

2. Game ini dapat mengubah mindset siswa, bahwa belajar juga bisa menjadi lebih menyenangkan

3. Game ini memiliki tampilan yang menarik sehingga dapat menambah minat siswa dalam belajar

4. Game ini menjadi bukti bahwa Game edukasi tidak kalah menarik dengan game non-edukasi

\section{Saran}
1. Menambahkan lebih banyak materi dan soal

2. Menambahkan menu atau fitur belajar

\section{DAFTAR PUSTAKA}

[1] Adita Rifai, Wafda. 2015. "Pengembangan Game Edukasi Lingkungan Berbasis Android". Skripsi. Universitas Negeri Yogyakarta: Yogyakarta.

[2] Deliana, Restu. 2015. "Pembuatan Game Komodo Island Adventure Untuk Memperkenalkan Satwa Komodo Sebagai Satwa Endemik Indonesia Dengan Metode Permainan Edugames Berbasis Desktop". Skripsi. Universitas Widyatama: Bandung.

[3] Suhendar, Akip. 2015. "Perancangan Game Edukasi pada SMPMN Cidahu kelas VII berbasis Multimedia" dalam Jurnal PROTEKINFO Volume 2 (hlm. 1).

[4] Dharma Bhakti, Demmy. 2017. "Game Edukasi Menara Hanoi Sebagai Salah Satu Alternatif Pembelajaran Logika Matematika Di SMK" dalam Jurnal Teknologi Pendidikan dan Pembelajaran Volume 2 Nomor 1 (hlm. 256).

[5] Kurniawan, Iwan. 2015. "Implementasi Pendidikan Bagi Siswa Tunanetra Di Sekolah Dasar Inklusi" dalam Edukasi 
Islami Jurnal Pendidikan Islam Volume 4 (hlm. 1044).

[6] Riwinoto, dan Arif Muspita, 2017. "Penerapan Multiplayer Pada Aplikasi Permainan Android" dalam Jurnal Politeknik Negeri Batam (hlm. 2).

[7] Vega Vitianingsih, Anik. 2016. "Game Edukasi Sebagai Media Pembelajaran Pendidikan Anak Usia Dini" dalam Jurnal INFORM Volume 1 Nomor 1(hlm. 25).

[8] Sumirah, Imas. 2019. "Perkembangan Kognitif Usia 3 Tahun Pertama", https://www.kompasiana.com/imas_sumira h/552c1bab6ea8348c4c8b4609/perkemban gan-kognitif-usia-3-tahun-pertama

Diakses pada tanggal 13 Juli 2019 pukul 11.50 .

[9] Syifa, Nayla. 2019. "Perkembangan Kognitif Usia 3 - 6 Tahun", https://www.kompasiana.com/naylasyifa/5 836c255e6afbd5209f08c29/perkembangan -kognitif-usia-3-6-tahun, Diakses pada tanggal 13 Juli 2019 pukul 11.55 .

[10] Asta Sari, Yuli. 2019. "Perkembangan Kognitif Anak Usia 7-12 Tahun (Masa Kanak-kanak)", https://www.kompasiana.com/asta11/583 67e7363afbdcf1c5ae879/perkembangankognitif-anak-usia-712-tahun-masakanakkanak, Diakses pada tanggal 13 Juli 2019 pukul 12.01 .

[11] Eki Pribadi, Ganteng. dkk. 2016. "Aplikasi Pembelajaran Bahasa Sunda Dengan Implementasi Algoritma Linear Congruential Generator Dan Fuzzy Berbasis Android" dalam Jurnal JOIN Volume 1 Nomor 1(hlm. 35).

[12] Madcoms. 2018. Memanfaatkan Aplikasi Android Pada Sistem Operasi Windows. Yogyakarta: Andi Publisher.
[13] Roedavan, Rickman. 2017. Construct 2 Tutorial Game Engine. Bandung: INFORMATIKA.

[14] Maulana Husein, Sultan (Penterjemah). 2019. "What is Adobe Phonegap", https://build.phonegap.com , Diakses pada tanggal 30 Juni 2019 pukul 22.36.

[15] Waskito, Danang. 2014. "Media Pembelajaran Interaktif Matematika Bagi Sekolah Dasar Kelas 6 Berbasis Multimedia" dalam peed Journal Sentra Penelitian Engineering dan Edukasi Volume 11 Nomor 3(hlm. 62).

[16] A.S, Rosa. dkk. 2016. Rekayasa Perangkat Lunak. Bandung: INFORMATIKA.

[17] Khotimah, Khusnul dan Hestya Patrie. 2018. "Rancang Bangun Sistem Informasi Poin Pelanggaran Tata Tertib Pada SMP Cenderawasih II Dengan Metodologi Berorientasi Obyek" dalam urnal IDEALIS Volume 1 Nomor 3(hlm. 238).

[18] Yasin Al Irsyadi, Fatah dan Yusuf Sulistyo Nugroho. 2015. "Game Edukasi Pengenalan Anggota Tubuh dan Pengenalan Angka Untuk Anak Berkebutuhan Khusus (ABK) Tunagrahita Berbasis Kinect" dalam Jurnal Prosiding SNATIF Volume 2 (hlm. 15).

[19] Wahyudi, Rizki. dkk. 2016. "Sistem Pakar E-Tourism Pada Dinas Pariwisata D.I.Y Menggunakan Metode Forward Chaining" dalam Jurnal Ilmiah DASI Volume 17 (hlm. 74).

[20] Syofian, Suzuki. 2015. "Otomatisasi Metode Penelitian Skala Likert Berbasis Web" dalam Jurnal PROSIDING SEMNASTEK (hlm. 2). 